\title{
Physical and Chemical Characteristics of Drinking Water in Coastal Area of Taluka Keti Bandar, Sindh, Pakistan: A Case Study
}

\author{
Abdul Raheem Shar ${ }^{1 *}$, Ghulam Qadir Shar ${ }^{1}$, Wahid Bux Jatoi ${ }^{1}$, Noor Zaman ${ }^{2}$, \\ Zubeda Bhatti ${ }^{3}$, Noor Ul Hassan ${ }^{1}$, Mazhar Iqbal Khaskheli ${ }^{4}$, Qurat-Ul-Ain Shaikh ${ }^{5}$, \\ Ghulam Mujtaba Jogi ${ }^{1}$ and Atta Hussain Rind ${ }^{1}$ \\ ${ }^{1}$ Institute of Chemistry, Shah Abdul Latif University, Khairpur, Sindh, Pakistan. \\ ${ }^{2}$ National Center of Excellence in Analytical Chemistry, University of Sindh, Jamshoro, Pakistan. \\ ${ }^{3}$ Department of Physics, Shah Abdul Latif University, Kheirpur, Sindh, Pakistan. \\ ${ }^{4}$ Department of Chemistry, Government College University, Hyderabad, Pakistan. \\ ${ }^{5}$ Department of Chemistry, Shaheed Benazir Bhutto University, Shaheed Benazirabad, Pakistan. \\ *Corresponding Author Email: saifiraheem3863920@gmail.com \\ Received 14 April 2020, Revised 08 June 2020, Accepted 11 June 2020
}

\begin{abstract}
The present study was carried out for quantitative assessment of the drinking water quality consumed by people of area under study. Physico-chemical parameters like $\mathrm{pH}, \mathrm{TH}, \mathrm{EC}, \mathrm{TDS}, \mathrm{Cl}^{-}$, $\mathrm{SO}_{4}{ }^{2-} \mathrm{HCO}_{3}{ }^{-}, \mathrm{NO}_{3}{ }^{-} \mathrm{N}, \mathrm{o}-\mathrm{PO}_{4}{ }^{3-}-\mathrm{P}, \mathrm{F}^{-}$, and Turbidity were determined. Titration and spectroscopic methods were used to analyze $\mathrm{SO}_{4}{ }^{2-}, \mathrm{NO}_{3}{ }^{-}-\mathrm{N}, \mathrm{o}-\mathrm{PO}_{4}{ }^{3-}-\mathrm{P}, \mathrm{F}^{-}$, and Turbidity. The $\mathrm{Ca}^{2+}$ and $\mathrm{Mg}^{2+}$ were measured with complexometric titration procedure, while $\mathrm{Na}^{+}$and $\mathrm{K}^{+}$were determined by FAAS. The study showed that $\mathrm{pH}$, nitrate-nitrogen and fluoride were found within the safe limit of the WHO. The TDS (1000 mg/L) and EC (1500 mg/L) of twelve villages were found above permissible limit. Samples of two villages Ali Hassan Mirgh Baloch and Pir Usman Shah Jhaloo showed high TH content. The chloride content was found within the safe limit only in three villages M. Essa Khaskheli, Abdullah Mallah and Haji Gul Muhammad Jat, whereas higher chloride content was found in the remaining villages. Higher sulfate content of $292 \mathrm{mg} / \mathrm{L}$ was observed in drinking water of Village Ali Ahmed Mirgh Baloch, while drinking water samples of all other villages under study were found safe for sulphate content. In the water of eight villages turbidity was found higher than allowable limit of 5 (NTU). Concentration of macro elements such as, $\mathrm{Ca}^{2+}(191-33 \mathrm{mg} / \mathrm{L}), \mathrm{Mg}^{+2}(22-92 \mathrm{mg} / \mathrm{L}), \mathrm{Na}^{+}(56-345 \mathrm{mg} / \mathrm{L})$ and $\mathrm{K}^{+}(1-11 \mathrm{mg} / \mathrm{L})$ were measured in the groundwater samples. Analytical data revealed that there are different parameters which may cause aesthetic and health hazards in the studied area.
\end{abstract}

Keywords: Groundwater, Spectroscopic methods, Argentometric, Complexometric

\section{Introduction}

The water without harmful effects that can be used for drinking as well as cooking is said to be safe drinking water. Water is an essential commodity for survival of life. The consumption of water quantity varies with physical activity, age, health and atmospheric conditions [1]. Water available in the fractures of rock development and beneath the surface of earth in pore spaces of soil is known as groundwater. The aquifer is a utilizable quantity of water given by an unconsolidated deposit or rock unit and the water table is the depth in which spaces in the soils and rocks are totally saturated with water. Near to the coastline of the sea, recharge aquifer area is likely to be inland, even at 
considerable space. Seawater may be induced to back water flow in a lowered water table towards the land-living. Seawater intrusion is a movement of seawater towards inland or discharge of salt beds into groundwater on its own concurrence [2].

The contamination of groundwater is different at different locations as well as depth of the bore of hand pump. Because of the unavailability of treatment of hygienic water and water supply, most of rural populations rely on the groundwater resources. Reports reveal that $40 \%$ of fatalities are caused due to consumption of contaminated water directly or indirectly all over the world [3]. Considerable work has been done on groundwater as well as on its quality in various areas of Pakistan, i.e., Taluka Nawabshah, Hazara Strip, Nawabshah city, lower Indus Basin, Pakistan, Taluka Daur, Rawal Dam Islamabad, Goth Ibrahim Hyderi, Karachi, Sindh Industrial Trading Estate Karachi and Ground water quality of selected areas of Punjab and Sind Provinces [4-11]. Human health may directly or indirectly be linked to greater or lower level of physical and chemical parameters in potable water [12]. The direct association between $\mathrm{pH}$ of water and public health is not observed, whereas it may indirectly affect some of the qualities of water, for instance, pathogen survival, solubility of ions and other pollutants. Bitter taste of water may be observed due to alkaline nature, while corrosive taste is related to its acidic nature [13, 14]. Moreover, potassium in the human body is believed as one of the trace metals, since its insufficiency may cause kidney problem, bladder swelling, high blood pressure and cardiovascular disease. High concentration of potassium may lead reduced renal function, high heart beating, ovarian cyst and irregular metabolism of protein [15-17]. Mineral water is the major resource of $\mathrm{Na}$ for human body requirement. Since the sodium deficiency in the body may cause dehydration, mental indifference, fatigue, depression and low blood pressure. Intake of high sodium content may lead nausea, headache, stomach-ache, kidney failure, edema, stroke and high blood pressure [18]. Cardiovascular diseases are related due to deficiency of some cations in the drinking water like $\mathrm{Ca}^{2+}$ and $\mathrm{Mg}^{2+}$. Major pollutants in the groundwater resources include nitrates and nitrites, which may increase due to overexploitation of resources of aquifers and groundwater, agricultural and industrial sewage and development of urbanization. The Methemoglobinomia in children may be caused by nitrite and nitrate content [19]. The excess level of nitrate is very toxic to infants because the bacteria in the infant's digestive system can change the nitrate into nitrite. Nitrite can lead to most significant disease methemoglobin and may cause brain damage or even death [20].

Low level of fluoride is beneficial for humans as it protects tooth enamel against the acids that cause tooth decay. [21, 22]. High fluoride content exposure in long term may cause Alzheimer and neurological troubles, skeletal and dental fluorosis. Digestive disorders and violent diarrhoea could be caused due to high sulphate content in drinking water [23]. Direct association of water quality with human health is reported [24]. It is therefore important to monitor water quality to prevent any health hazards and protect water resources. A large area of world is utilized for cultivation depending upon the groundwater as well as fresh water. Water resources in the coastal area are severely influenced due to seawater intrusion. In Pakistan, population is increasing at alarming rates, depleting freshwater resources and the significance of groundwater monitoring is enhanced. Pakistan is land region, vulnerable against environmental variation and is usually has semi-dry and bone-dry areas [25]. Taluka Keti Bandar belongs to district Thatta that is coastal area of Sindh Pakistan, where freshwater accessibility is a critical issue for the livelihood and survival of people of the area. Since drinking water source for them is only River Indus as well as its canal system. Drinking water resources may be contaminated due to metals, sewage leaks and agricultural run-off. Although, consumers of drinking water are unable to assess the safe water apart from its taste. Therefore, innocent people are consuming contaminated water, and are unable to raise queries regarding its quality. The problem is further aggravated due to decreased flow in the River Indus at downstream as well as growing changeability in rainfall pattern, which further decreases the water supply available for human utilization [26, 27]. 


\section{Aims of the study}

The coastal belt experiences hydrological changes due to human activities, sea intrusion, floods and other natural disasters rendering ground water unsafe for drinking purpose. Therefore, its quality assessment was carried out to determine the physical and chemical status of drinking water of the study area.

\section{Materials and Methods Study area}

Keti Bandar is located in Thatta district, Sindh, Pakistan. It is a port on the Arabian Sea. Keti Bandar port was made on the vestiges of the older Debal harbour which was arrival point of Muhammad Bin Qasim along with his army. The driving time of about 3.5-4 h from Keti Bandar to Karachi was observed with a distance of about 150 $\mathrm{km}$. Mirpur Sakro and Gharo are the two major towns on the route from Keti Bandar to Karachi. The economy of Keti Bandar totally depends upon fishing and about all people of the area are fishermen. The fish caught by fishermen form Arabian Sea, transport their product to Karachi [28]. According to the census of 2019, the population of the study area is 58,832. The study area has hot desert climate. The regular annual rain fall in study area is $210 \mathrm{~mm}$, while average annual temperature is about $26.8^{\circ} \mathrm{C}$ [29].

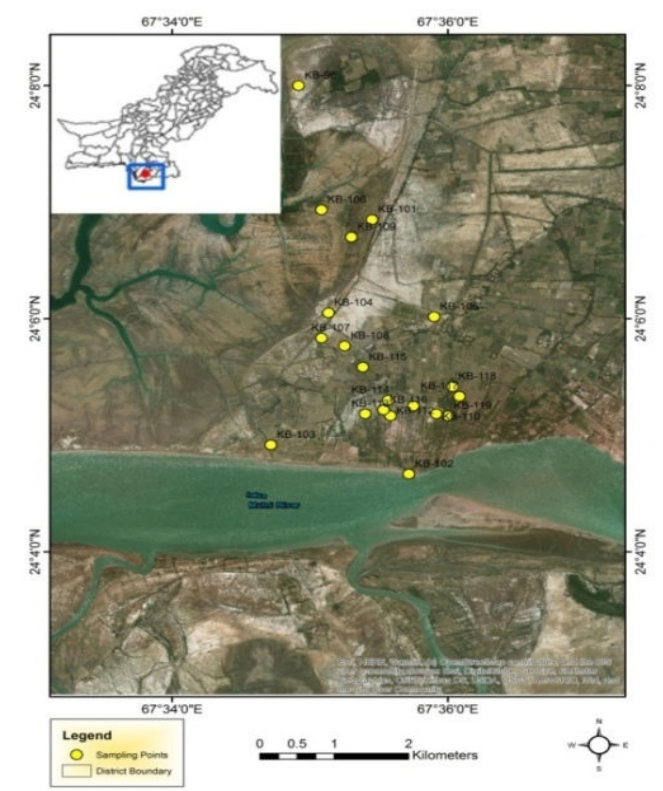

Figure 1. Map of sampling of drinking water area under study

\section{Samples collection}

Sampling bottles were washed thoroughly with detergent and then with distilled water. At the time of sampling bottles were rinsed with same sample thrice. Triplicate samples from each sampling point were collected and covered tightly. Usually hand pumps were fitted by villagers to get groundwater for drinking, cooking and washing purposes. Ground water source was run for 2-5 min. till fresh water comes out [30]. The depths of water sources were found 15 - 25 feet in different villages of study area. Sampling locations include Baghan Town, Pir Usman Shah Jhaloo, Ali Hassan Mirgh Baloch, Manjhi Khan Baloch, Manjhi Khan Baloch, Nathoo Khan, Haji Qadir Bux Baloch, Sajjan Wari, M. Hassan Perozani Baloch, Haji Yaqoob Memon, Hajii Gul Muhammad Jat, Abdullah Khatri, Abdullah Mallah, M. Essa Khaskheli, Esso Baloch, Ali Muhammad Utradi and Rana Mori. GPS was used to record the DMS coordinates of sampling points for authenticity of results (Table 1). The standard methods were followed during all analyses [31].

Table 1. Names and abbreviations of villages from Taluka Keti Bander along with DMS Coordinates taken with GPS device.

\begin{tabular}{|c|c|c|c|c|}
\hline Villages & Abbreviation & $\begin{array}{l}\text { Depth } \\
\text { (Feet) }\end{array}$ & $\begin{array}{r}\text { Water } \\
\text { source }\end{array}$ & $\begin{array}{c}\text { DMS } \\
\text { Coordinates }\end{array}$ \\
\hline$\overline{\text { Rana Mori }}$ & R.M & ----- & $\begin{array}{l}\text { Surface } \\
\text { water }\end{array}$ & $\begin{array}{l}24^{\circ} 08^{\prime} 39^{\prime \prime} \mathrm{N} \\
67^{\circ} 27^{\prime} 02^{\prime \prime} \mathrm{E}\end{array}$ \\
\hline $\begin{array}{l}\text { Ali Muhammad } \\
\text { Utradi }\end{array}$ & A.M.U & 18 & $\begin{array}{l}\text { Hand } \\
\text { Pump }\end{array}$ & $\begin{array}{l}24^{\circ} 03^{\prime} 18^{\prime \prime} \mathrm{N} \\
67^{\circ} 35^{\prime} 55^{\prime \prime} \mathrm{E}\end{array}$ \\
\hline Esso Baloch & E.B & 18 & $\begin{array}{l}\text { Hand } \\
\text { Pump }\end{array}$ & $\begin{array}{l}24^{\circ} 04^{\prime} 33^{\prime \prime} \mathrm{N} \\
67^{\circ} 33^{\prime} 48^{\prime \prime} \mathrm{E}\end{array}$ \\
\hline $\begin{array}{l}\text { M. Essa } \\
\text { Khaskheli }\end{array}$ & M.E.K & 15 & $\begin{array}{l}\text { Hand } \\
\text { Pump }\end{array}$ & $\begin{array}{l}24^{\circ} 04^{\prime} 44^{\prime \prime} \mathrm{N} \\
67^{\circ} 32 ' 55^{\prime \prime} \mathrm{E}\end{array}$ \\
\hline Abdullah Mallah & A.M & 15 & $\begin{array}{l}\text { Hand } \\
\text { Pump }\end{array}$ & $\begin{array}{l}24^{\circ} 05^{\prime} 52^{\prime \prime} \mathrm{N} \\
67^{\circ} 35^{\prime} 56^{\prime \prime} \mathrm{E}\end{array}$ \\
\hline Abdullah Khatri & A.K & 18 & $\begin{array}{l}\text { Hand } \\
\text { Pump }\end{array}$ & $\begin{array}{l}24^{\circ} 08^{\prime} 39^{\prime \prime} \mathrm{N} \\
67^{\circ} 22^{\prime} 56^{\prime \prime} \mathrm{E}\end{array}$ \\
\hline $\begin{array}{l}\text { Hajii Gul } \\
\text { Muhammad Jat }\end{array}$ & H.G.M.J & 20 & $\begin{array}{l}\text { Hand } \\
\text { Pump }\end{array}$ & $\begin{array}{l}24^{\circ} 09^{\prime} 43^{\prime \prime} \mathrm{N} \\
67^{\circ} 34^{\prime} 16^{\prime \prime} \mathrm{E}\end{array}$ \\
\hline $\begin{array}{l}\text { Haji Yaqoob } \\
\text { Memon }\end{array}$ & H.Y.M & 25 & $\begin{array}{l}\text { Hand } \\
\text { Pump }\end{array}$ & $\begin{array}{l}24^{\circ} 06^{\prime} 01^{\prime \prime} \mathrm{N} \\
67^{\circ} 35^{\prime} 54^{\prime \prime} \mathrm{E}\end{array}$ \\
\hline $\begin{array}{l}\text { M. Hassan } \\
\text { Perozani Baloch }\end{array}$ & M.H.P.B & 20 & $\begin{array}{l}\text { Hand } \\
\text { Pump }\end{array}$ & $\begin{array}{l}24^{\circ} 06^{\prime} 03^{\prime \prime} \mathrm{N} \\
67^{\circ} 35^{\prime} 08^{\prime \prime} \mathrm{E}\end{array}$ \\
\hline Sajjan Wari & S.W & 18 & $\begin{array}{l}\text { Hand } \\
\text { Pump }\end{array}$ & $\begin{array}{l}24^{\circ} 04^{\prime} 55^{\prime \prime} \mathrm{N} \\
67^{\circ} 34^{\prime} 43^{\prime \prime} \mathrm{E}\end{array}$ \\
\hline $\begin{array}{l}\text { Haji Qadir Bux } \\
\text { Baloch }\end{array}$ & H.Q.B.B & 18 & $\begin{array}{l}\text { Hand } \\
\text { Pump }\end{array}$ & $\begin{array}{l}24^{\circ} 04^{\prime} 40^{\prime \prime} \mathrm{N} \\
67^{\circ} 35^{\prime} 43^{\prime \prime} \mathrm{E}\end{array}$ \\
\hline Nathoo Khan & N.K & 20 & $\begin{array}{l}\text { Hand } \\
\text { Pump }\end{array}$ & $\begin{array}{l}24^{\circ} 06^{\prime} 51^{\prime \prime} \mathrm{N} \\
68^{\circ} 17^{\prime} 41^{\prime \prime} \mathrm{E}\end{array}$ \\
\hline $\begin{array}{l}\text { Manjhi Khan } \\
\text { Baloch }\end{array}$ & M.K.B & 18 & $\begin{array}{l}\text { Hand } \\
\text { Pump }\end{array}$ & $\begin{array}{l}24^{\circ} 08^{\prime} 34^{\prime \prime} \mathrm{N} \\
67^{\circ} 35^{\prime} 23^{\prime \prime} \mathrm{E}\end{array}$ \\
\hline $\begin{array}{l}\text { Ali Hassan } \\
\text { Mirgh Baloch }\end{array}$ & A.H.M.B & 18 & $\begin{array}{l}\text { Hand } \\
\text { Pump }\end{array}$ & $\begin{array}{l}24^{\circ} 08^{\prime} 58^{\prime \prime} \mathrm{N} \\
67^{\circ} 34^{\prime} 49^{\prime \prime} \mathrm{E}\end{array}$ \\
\hline $\begin{array}{l}\text { Pir Usman Shah } \\
\text { Jhaloo }\end{array}$ & P.U.S.J & 15 & $\begin{array}{l}\text { Hand } \\
\text { Pump }\end{array}$ & $\begin{array}{l}24^{\circ} 10^{\prime} 43^{\prime \prime} \mathrm{N} \\
67^{\circ} 34^{\prime} 49^{\prime \prime} \mathrm{E}\end{array}$ \\
\hline Baghan Town & B.T & 15 & $\begin{array}{l}\text { Hand } \\
\text { Pump }\end{array}$ & $\begin{array}{l}24^{\circ} 13^{\prime} 49^{\prime \prime} \mathrm{N} \\
67^{\circ} 36^{\prime} 36^{\prime \prime} \mathrm{E}\end{array}$ \\
\hline
\end{tabular}




\section{Sample analysis}

Standard procedures were followed for analyses of all samples [32]. Calibrated $\mathrm{pH}$ meter and EC meter were used to measure $\mathrm{pH}$ and conductivity of water at the sampling station. Electrical conductivity values were used to determine TDS in $\mathrm{mg} / \mathrm{L}$ using equation: TDS = $0.67 \times E C \times 1000$. Double beam spectrophotometer (CECIL CE 9500) was used to analyze $\mathrm{SO}_{4}{ }^{2-}$, $\mathrm{NO}_{3}{ }^{-} \mathrm{N}, o-\mathrm{PO}_{4}{ }^{3-}-\mathrm{P}, \mathrm{F}^{-}$, and Turbidity. Standard titration procedure was followed to determine the chloride content with $\mathrm{AgNO}_{3}$ standard solution. Standard $\mathrm{HCl}$ was used to measure concentration of $\mathrm{HCO}_{3}^{-}$. Standard solution of EDTA was used to measure the $\mathrm{TH}$ concentration, $\mathrm{Ca}$, and $\mathrm{Mg}$ content from water samples. Nephlometric turbidity meter was used to determine turbidity of the water. A flame photometer was used to measure sodium and potassium concentrations. Experimental work was carried out at the laboratory temperature of $25{ }^{\circ} \mathrm{C}$. For practical work, distilled water and A.R grade reagents were used. Concentrations of $\mathrm{SO}_{4}{ }^{2-}, \mathrm{NO}_{3}{ }^{-} \mathrm{N}, o-\mathrm{PO}_{4}{ }^{3-} \mathrm{P}$ and $\mathrm{F}^{-}$were measured from their calibration graphs.

\section{Results and Discussion}

Physical and chemical parameters included; $\mathrm{pH}$, TH, EC, TDS, $\mathrm{Cl}^{-}$, alkalinity, $\mathrm{SO}_{4}^{2-}$, $\mathrm{HCO}_{3}^{-}, \mathrm{NO}_{3}{ }^{-} \mathrm{N}, o-\mathrm{PO}^{3-}{ }_{4}^{-} \mathrm{P}, \mathrm{F}^{-}$, and turbidity are summarized in Table: 2. Maximum $\mathrm{pH}$ of 7.9 was measured from the groundwater of village Haji Gul Muhammad Jat which may be attributed to underground sulphide mineralization. Minimum $\mathrm{pH}$ of 7.1 was observed from village M. Hassan Perozani Baloch. Since the $\mathrm{pH}$ of groundwater of all villages was found within permissible limit of Pakistan and WHO guideline [33] (Table 2, 3 and Fig. 2).

Calcium (Ca), magnesium ( $\mathrm{Mg}$ ) and other metals existing in water are responsible for total hardness [34]. The range of TH was observed between $66-694 \mathrm{mg} / \mathrm{L}$. The drinking water of two villages showed TH level greater than allowable limit (Table 2, 3 and Fig. 3).
Potential of water to carry electricity is measured in electrical conductance [35]. Electrical conductance of villages under study was found between 913 and $3580 \mu \mathrm{S} / \mathrm{cm}$. Four villages showed higher electrical conductivity than the WHO permissible level while, drinking water of twelve villages was found within safe limit. Higher conductance of groundwater may be due to the soluble species, ionic specie and soluble salts (Table 2, 3 and Fig. 4).

Dissolved substances such as, cations, anions, salts, minerals and elements present in water make total dissolved solids. Diseases may be caused due to high TDS concentrations in drinking water for instance heart disease, stomach irritation and kidney stones [36]. The TDS values ranged from $612-2399 \mathrm{mg} / \mathrm{L}$ in the water of coastal area was measured while average TDS content was measured as $1273 \mathrm{mg} / \mathrm{L}$. The TDS of twelve villages were above and only four villages were within the permissible limits of WHO (2012). Geological nature of soil in groundwater may be responsible for higher TDS levels (Table 2, 3 and Fig. 5).

Chloride content may be found in groundwater as well as surface water [37]. From the study area, chloride level was found between 174 and $604 \mathrm{mg} / \mathrm{L}$. Thirteen villages showed chloride content above the WHO level of 250 $\mathrm{mg} / \mathrm{L}$, whereas, only three villages declared chloride content within permissible limit (Table 2, 3 and Fig. 6).

Bicarbonate, carbonates and hydroxide in water are responsible for alkalinity of water. The major sources of alkalinity of water are weathering of rocks as well as sediments. Crop production may be reduced by damaging soil, since its higher concentration in water may produce bitter taste [38] (Table 2, 3 and Fig. 7).

The range of alkalinity from groundwater of Taluka Keti Bandar was analyzed from 330 to $588 \mathrm{mg} / \mathrm{L}$. Alkalinity values of groundwater of all villages was found above allowable limit of 300 $\mathrm{mg} / \mathrm{L}$. Maximum and minimum bicarbonate content of 120 and $460 \mathrm{mg} / \mathrm{L}$ was measured from 
area under study with average concentration of $264 \mathrm{mg} / \mathrm{L}$ (Table 2, 3 and Fig. 8).

All natural waters contain sulphate $\left(\mathrm{SO}_{4}{ }^{2-}\right)$, since its high concentration may cause gastrointestinal pain. The diseases known as cathartic may be caused by $\mathrm{SO}_{4}{ }^{2-}$ when its concentration is greater than $600 \mathrm{mg} / \mathrm{L}$ [39]. The $\mathrm{SO}_{4}{ }^{2-}$ content determined from study area was between 49 and $292 \mathrm{mg} / \mathrm{L}$. only one village declared $\mathrm{SO}_{4}{ }^{2-}$ content above allowable limit (250 $\mathrm{mg} / \mathrm{L}$ ), although fifteen villages were declared within allowable limit (Table 2, 3 and Fig. 9).

The foremost groundwater pollutants include nitrates and nitrites. The origin of the nitrates may be due to industrial effluents, septic tanks and fertilizers. The higher nitrate content is extremely toxic to babies having age less than four months, since bacteria in the in the digestive system of children may convert nitrate into nitrite. High nitrate content may cause brain damage, methemoglobin, and fatality [40]. The WHO permissible level of water is $10 \mathrm{mg} / \mathrm{L}$. Nitrate nitrogen in the entire samples of groundwater of the area under study was found within safe level, though nitrate nitrogen was determined between 1.0 and $9.0 \mathrm{mgL}^{-1}$. The Mean value of $4.38 \mathrm{mg} / \mathrm{L}$ of nitrate nitrogen was calculated from the water of area under study (Table 2, 3 and Fig. 10).

Groundwater may get phosphorus from organic matter, industrial wastages, detergents, agricultural fertilizers and manure. For human body phosphorus is the most significant element, since its higher content may cause kidney damage, osteoporosis and other health hazards [41]. The WHO limit of phosphate phosphorus for drinking water is recommended as $1.0 \mathrm{mg} / \mathrm{L}$, as no limit is determined for orthophosphate phosphorus. The concentration of orthophosphate phosphorus was ranged between 0.01 and $0.03 \mathrm{mg} / \mathrm{L}$ (Table 2, 3 and Fig. 11).

Groundwater and soil contain fluoride naturally, since the major sources of fluorides in groundwater include; fluorapatite, fluorite, hydroxyapatite, fluorspar, cryolite [42]. Tooth enamel is protected by low fluoride content and is therefore advantageous for humans against acids which may cause tooth decay. The nervous and muscles problems and weak bones may result due to the high fluoride concentration present in water. The fluoride content ranged from 0.17 to 0.36 $\mathrm{mg} / \mathrm{L}$ in potable water of area under study, since fluoride level of all villages under study was found within permissible limit (1.5 mg/L) (Table 2, 3 \& Fig. 12). A similar study reported higher values of water quality parameters of drinking water of Qamber-Shahdad District [43].

Turbidity of drinking water is allowed as 5 NTU, therefore turbidity lower than this level is ideal for drinking water [44]. No health based parameter is found; nonetheless microorganisms may adhere to the particulates present in water. As a result, health issue may be constituted indirectly due to turbid water having microorganisms. Therefore, microbiological quality as well as disinfection of water may be represented by turbidity. The turbidity of seven villages was found above the allowable limit whereas seven villages showed turbidity within permissible limit of the WHO (5 NTU). The range of turbidity was measured between 0.25 and 2.3 NTU (Table 2, 3 and Fig. 13).

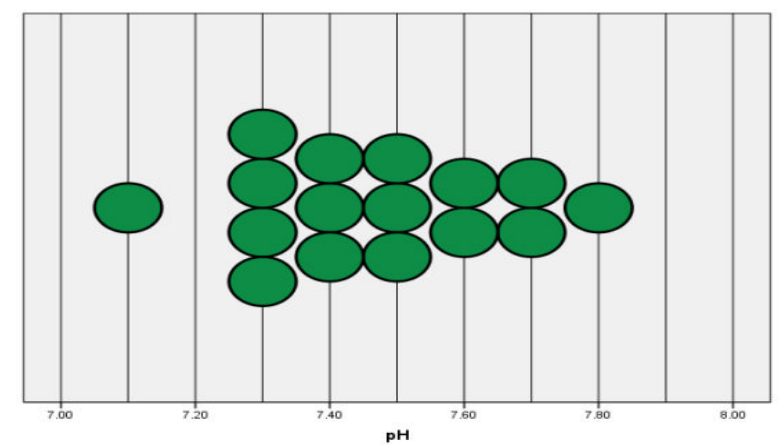

Figure 2. pH

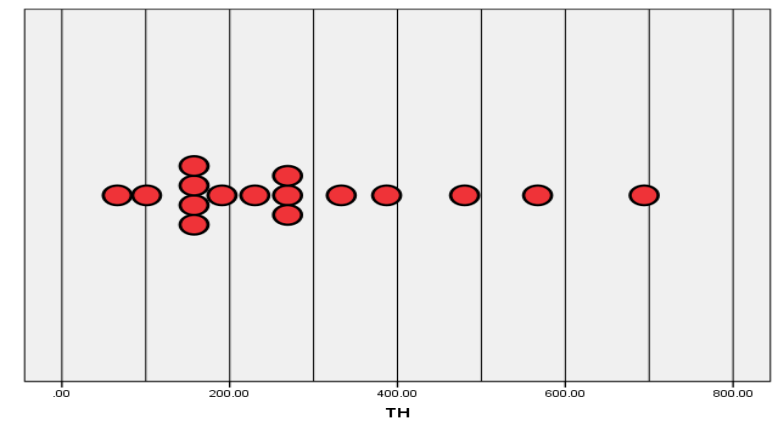

Figure 3. TH 
Pak. J. Anal. Environ. Chem. Vol. 21, No. 1 (2020)

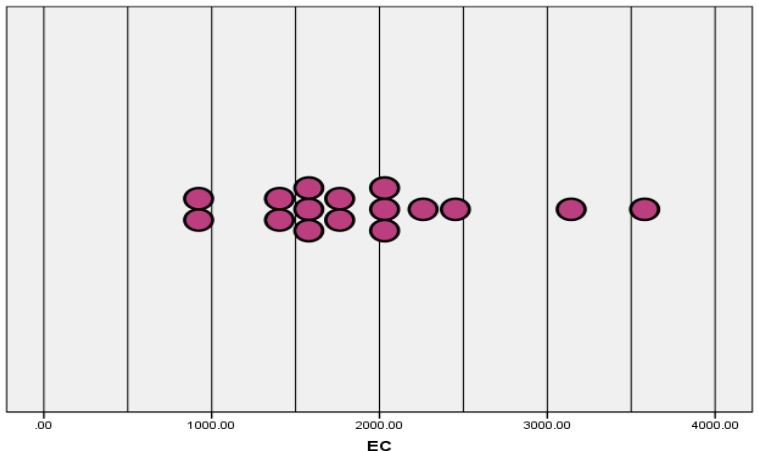

Figure 4. EC

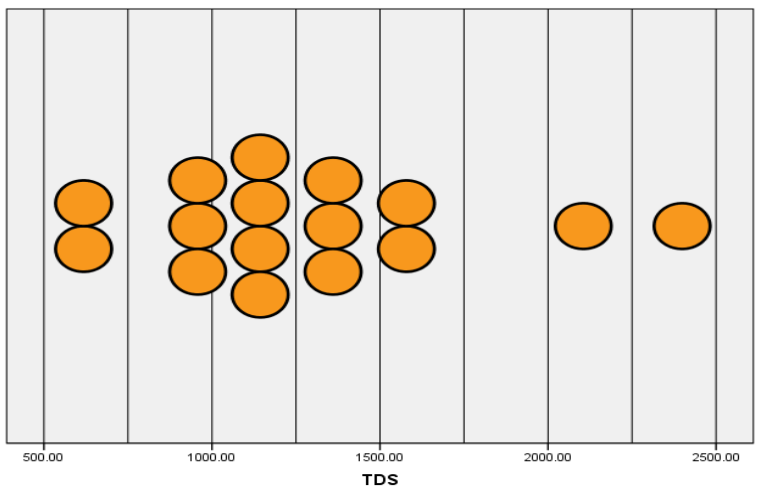

Figure 5. TDS

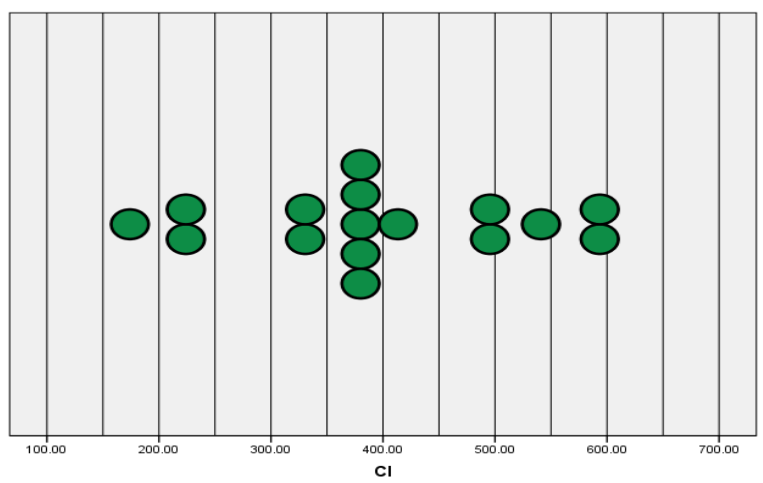

Figure 6. $\mathrm{Cl}^{-}$

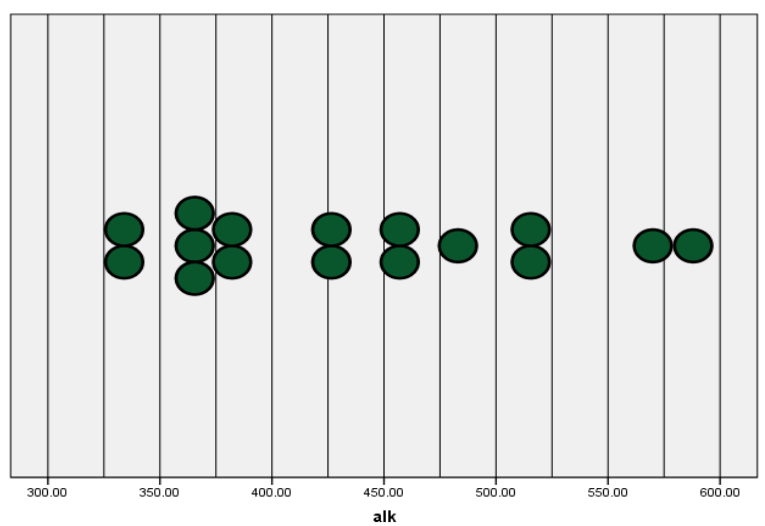

Figure 7. Alk

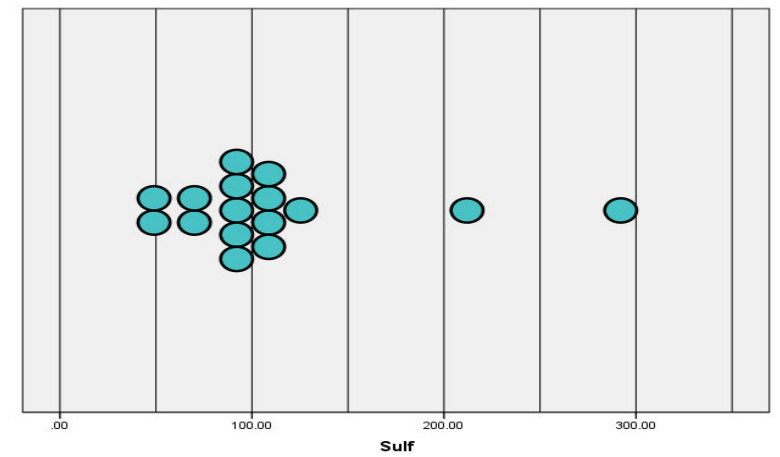

Figure 8. Sulfate

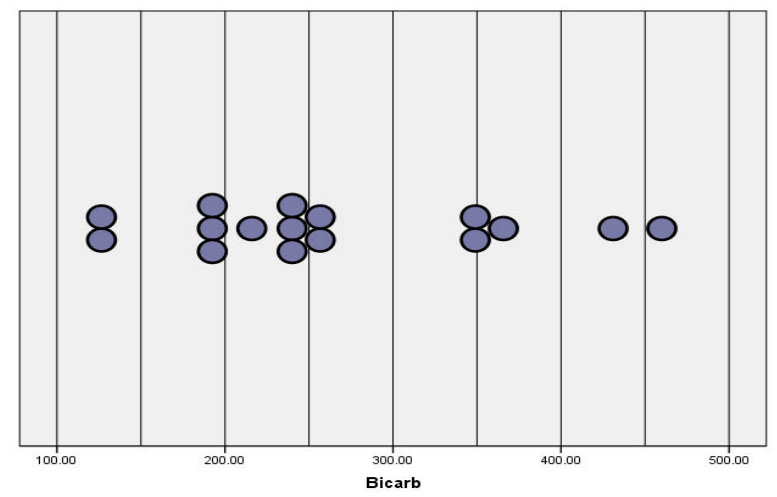

Figure 9. Bicarbonate

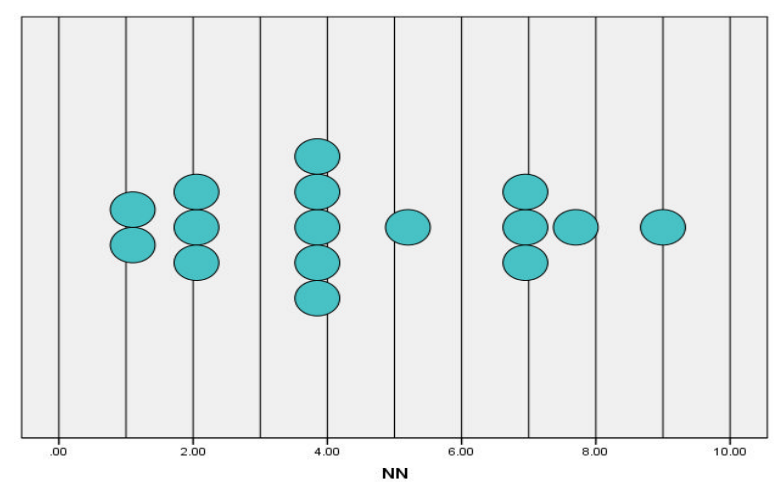

Figure 10. Nitrate-N

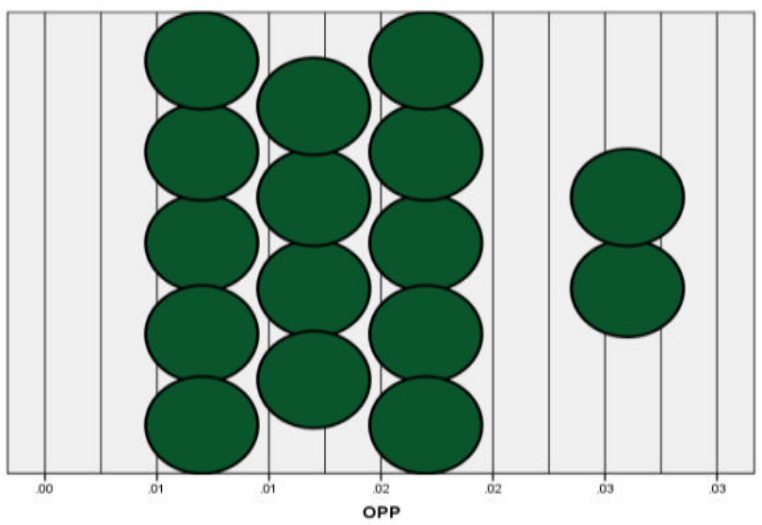

Figure 11. o-PP 


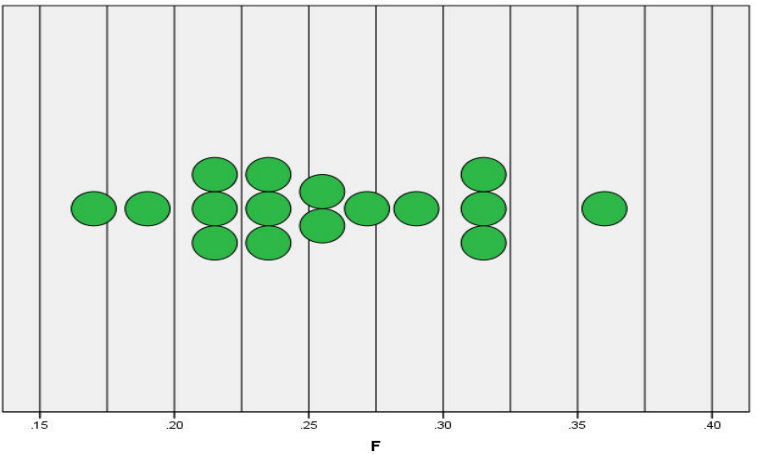

Figure 12. $\mathrm{F}^{-}$

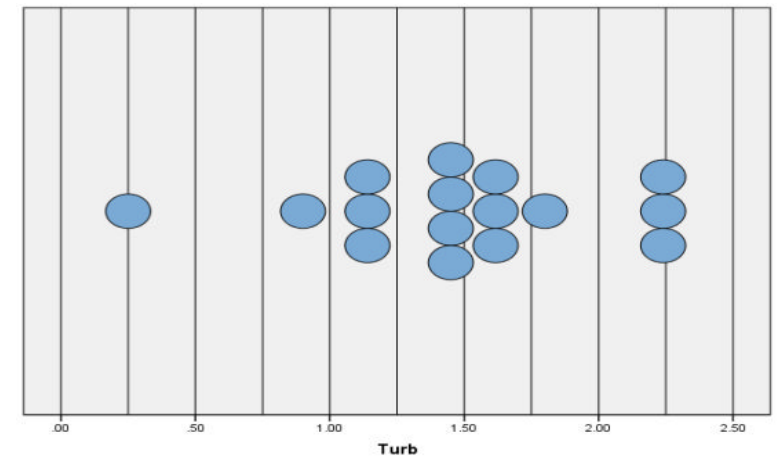

Figure 13. Turbidity

Figures 2-13. Shows scatter plots of physicochemical parameters of area under study

Table 2. Mean Concentration of physical and chemical parameters in drinking water of area under study.

\begin{tabular}{|c|c|c|c|c|c|c|}
\hline Villages & $\mathrm{pH} \pm \mathrm{SD}$ & TH $(\mathrm{mg} / \mathrm{L}) \pm \mathrm{SD}$ & $\mathrm{EC}(\mu \mathrm{S} / \mathrm{cm}) \pm \mathrm{SD}$ & TDS (mg/L) \pm SD & $\mathrm{Cl}^{-}(\mathrm{mg} / \mathrm{L}) \pm \mathrm{SD}$ & Alk (mg/L) $\pm S D$ \\
\hline R.M & $7.5 \pm 0.13$ & $150 \pm 0.75$ & $913 \pm 1.628$ & $612 \pm 1.71$ & $382 \pm 1.06$ & $388 \pm 1.84$ \\
\hline A.M.U & $7.5 \pm 0.12$ & $101 \pm 0.68$ & $1806 \pm 1.702$ & $1210 \pm 1.58$ & $390 \pm 1.11$ & $588 \pm 1.83$ \\
\hline E.B & $7.7 \pm 0.12$ & $66 \pm 0.72$ & $1607 \pm 1.086$ & $1077 \pm 1.74$ & $390 \pm 1.17$ & $338 \pm 1.83$ \\
\hline M.E.K & $7.4 \pm 0.15$ & $171 \pm 0.66$ & $1332 \pm 1.70$ & $893 \pm 1.69$ & $240 \pm 1.18$ & $363 \pm 1.86$ \\
\hline A.M & $7.6 \pm 0.17$ & $144 \pm 1.34$ & $1525 \pm 1.39$ & $1022 \pm 1.64$ & $208 \pm 1.13$ & $372 \pm 1.88$ \\
\hline A.K & $7.7 \pm 0.11$ & $190 \pm 0.66$ & $1476 \pm 1.298$ & $989 \pm 2.03$ & $346 \pm 1.17$ & $330 \pm 1.98$ \\
\hline H.G.M.J & $7.8 \pm 0.02$ & $171 \pm 0.70$ & $931 \pm 1.661$ & $624 \pm 1.71$ & $174 \pm 1.21$ & $455 \pm 2.01$ \\
\hline H.Y.M & $7.4 \pm 0.18$ & $265 \pm 0.70$ & $1632 \pm 1.021$ & $1093 \pm 2.09$ & $315 \pm 1.19$ & $427 \pm 1.71$ \\
\hline M.H.P.B & $7.1 \pm 0.23$ & $266 \pm 2.25$ & $2452 \pm 1.41$ & $1643 \pm 1.71$ & $604 \pm 1.18$ & $509 \pm 1.76$ \\
\hline S.W & $7.3 \pm 0.64$ & $480 \pm 7.22$ & $2106 \pm 1.62$ & $1411 \pm 2.02$ & $487 \pm 1.18$ & $376 \pm 1.82$ \\
\hline H.Q.B.B & $7.6 \pm 0.13$ & $387 \pm 1.47$ & $1958 \pm 1.592$ & $1312 \pm 1.99$ & $504 \pm 1.21$ & $359 \pm 1.83$ \\
\hline N.K & $7.5 \pm 0.12$ & $333 \pm 0.68$ & $2260 \pm 1.534$ & $1514 \pm 2.05$ & $583 \pm 1.23$ & $426 \pm 1.78$ \\
\hline M.K.B & $7.4 \pm 0.15$ & $230 \pm 0.66$ & $1955 \pm 1.345$ & $1310 \pm 1.95$ & $541 \pm 1.33$ & $459 \pm 1.82$ \\
\hline A.H.M.B & $7.3 \pm 0.16$ & $694 \pm 0.69$ & $3580 \pm 1.565$ & $2399 \pm 1.77$ & $394 \pm 1.36$ & $522 \pm 1.86$ \\
\hline P.U.S.J & $7.3 \pm 0.12$ & $567 \pm 0.63$ & $3142 \pm 1.473$ & $2105 \pm 1.67$ & $408 \pm 1.37$ & $570 \pm 1.73$ \\
\hline B.T & $7.3 \pm 0.12$ & $273 \pm 0.66$ & $1720 \pm 1.311$ & $1153 \pm 1.72$ & $366 \pm 1.32$ & $483 \pm 1.75$ \\
\hline
\end{tabular}

Table 3. Concentration of physical and chemical parameters in drinking water of area under study .

\begin{tabular}{|c|c|c|c|c|c|c|}
\hline Villages & $\begin{array}{c}\mathrm{SO4}^{2-} \\
(\mathrm{mg} / \mathrm{L}) \pm \mathrm{SD} \\
\end{array}$ & $\begin{array}{c}\mathrm{HCO}_{3}^{-} \\
(\mathrm{mg} / \mathrm{L}) \pm \mathrm{SD} \\
\end{array}$ & $\begin{array}{c}\mathrm{N}-\mathrm{N} \\
(\mathrm{mg} / \mathrm{L}) \pm \mathrm{SD}\end{array}$ & $\begin{array}{c}\text { o-PP } \\
(\mathrm{mg} / \mathrm{L}) \pm \mathrm{SD}\end{array}$ & $\begin{array}{c}\mathbf{F}^{-} \\
(\mathrm{mg} / \mathrm{L}) \pm \mathrm{SD}\end{array}$ & $\begin{array}{c}\text { Turb } \\
(\mathrm{NTU}) \pm \text { SD } \\
\end{array}$ \\
\hline R.M & $49 \pm 0.82$ & $120 \pm 0.25$ & $2.1 \pm 0.16$ & $0.015 \pm 0.0003$ & $0.24 \pm 0.02$ & $1.2 \pm 0.09$ \\
\hline A.M.U & $119 \pm 0.67$ & $255 \pm 0.10$ & $6.7 \pm 0.21$ & $0.009 \pm 0.0004$ & $0.22 \pm 0.01$ & $1.5 \pm 0.12$ \\
\hline E.B & $104 \pm 0.93$ & $188 \pm 0.24$ & $3.8 \pm 0.15$ & $0.025 \pm 0.0003$ & $0.27 \pm 0.00$ & $1.6 \pm 0.12$ \\
\hline M.E.K & $67 \pm 0.87$ & $247 \pm 0.19$ & $3.7 \pm 0.12$ & $0.007 \pm 0.0002$ & $0.17 \pm 0.02$ & $2.20 \pm 0.10$ \\
\hline A.M & $99 \pm 0.89$ & $354 \pm 0.58$ & $7.7 \pm 0.50$ & $0.008 \pm 0.0004$ & $0.32 \pm 0.02$ & $1.40 \pm 0.09$ \\
\hline A.K & $73 \pm 1.17$ & $185 \pm 0.73$ & $4 \pm 0.64$ & $0.013 \pm 0.0007$ & $0.25 \pm 0.01$ & $1.45 \pm 0.11$ \\
\hline H.G.M.J & $49 \pm 0.71$ & $133 \pm 0.62$ & $1 \pm 0.53$ & $0.005 \pm 0.0009$ & $0.36 \pm 0.02$ & $0.25 \pm 0.09$ \\
\hline H.Y.M & $104 \pm 0.68$ & $216 \pm 0.50$ & $4 \pm 0.41$ & $0.0100 \pm 0.001$ & $0.21 \pm 0.00$ & $1.08 \pm 0.08$ \\
\hline M.H.P.B & $99 \pm 0.74$ & $361 \pm 0.57$ & $6.7 \pm 0.48$ & $0.006 \pm 0.0004$ & $0.32 \pm 0.01$ & $1.8 \pm 0.10$ \\
\hline S.W & $88 \pm 0.83$ & $344 \pm 0.75$ & $7.2 \pm 0.66$ & $0.018 \pm 0.0001$ & $0.24 \pm 0.01$ & $1.4 \pm 0.11$ \\
\hline H.Q.B.B & $110 \pm 0.94$ & $233 \pm 0.87$ & $3.8 \pm 0.78$ & $0.013 \pm 0.0002$ & $0.23 \pm 0.03$ & $2.3 \pm 0.12$ \\
\hline N.K & $100 \pm 0.87$ & $238 \pm 0.70$ & $5.2 \pm 0.61$ & $0.019 \pm 0.0011$ & $0.19 \pm 0.02$ & $1.1 \pm 0.11$ \\
\hline M.K.B & $84 \pm 0.77$ & $200 \pm 0.24$ & $1.2 \pm 0.15$ & $0.019 \pm 0.0002$ & $0.29 \pm 0.02$ & $0.9 \pm 0.100$ \\
\hline A.H.M.B & $292 \pm 10$ & $460 \pm 0.14$ & $9 \pm 0.18$ & $0.012 \pm 0.0000$ & $0.31 \pm 0.03$ & $1.62 \pm 0.12$ \\
\hline P.U.S.J & $212 \pm 0.63$ & $431 \pm 0.31$ & $2 \pm 0.22$ & $0.027 \pm 0.0004$ & $0.26 \pm 0.01$ & $1.58 \pm 0.11$ \\
\hline B.T & $102 \pm 0.95$ & $256 \pm 0.78$ & $2 \pm 0.69$ & $0.017 \pm 0.0002$ & $0.218 \pm 0.01$ & $2.18 \pm 0.01$ \\
\hline
\end{tabular}




\section{Cations}

Very low or very high concentrations of $\mathrm{Ca}$ and $\mathrm{Mg}$ or total hardness in drinking water have been empirically recognized as the cause of the problems with corrosion, scaling, or taste of water. A large body of scientific evidence over the last 60 years has also attributed health problems to both extremes of these minerals in water. For example, drinking water low in $\mathrm{Mg}$ significantly increases the likelihood of cardiovascular mortality. This knowledge is not properly considered in the drinking water quality regulations, especially as more and more water is now produced by desalination disturbing its natural mineral composition [45]. Maximum and minimum $\mathrm{Ca}^{2+}$ level of observed between 33 and $191 \mathrm{mg} / \mathrm{L}$ and the mean concentration of 104 $\mathrm{mg} / \mathrm{L}$. the WHO level of $\mathrm{Ca}^{2+}$ for drinking water is suggested as $200 \mathrm{mg} / \mathrm{L}$, since all villages under study showed safe $\mathrm{Ca}^{2+}$ level (Table 4 and Fig. 14). Upper most and lower most $\mathrm{Mg}$ level of 22 and 92 $\mathrm{mg} / \mathrm{L}$ was measured from water of the different villages of studied area, since the average $\mathrm{Mg}$ concentration of $49 \mathrm{mg} / \mathrm{L}$ was determined from coastal area under study (Table 4 and Fig. 15).

Salts of sodium are not extremely toxic due to the effectiveness of expelling the sodium by mature kidneys. Although, death and severe effects for instance, pulmonary, and cerebral oedema, rigidity and muscular twitching, convulsions, vomiting and nausea have been published pursuing the unplanned overdoses of $\mathrm{NaCl}$ salt. Literature shows that due to ingestion of too much salt affects badly constant congestive heart failure as well as ill effects by presence of salt in drinking water. Permanent neurological disorder is found usual in conditions of severe gastrointestinal infections in children [46]. The concentration of $\mathrm{Na}^{+}$determined from groundwater of Taluka Keti Bandar was found higher than $200 \mathrm{mg} / \mathrm{L}$ in villages, Ali Muhammad Utradi, Esso Baloch, Muhammad Hassan Perozani Baloch, Sajan Wari, Haji Qadie Bux Baloch, Nathoo Khan, Manjhi Khan Baloch, Ali Hassan Mirgh Baloch, Pir Usman Shah Jhaloo and Baghan Town. Minimum and maximum $\mathrm{Na}^{+}$concentration was ranged from 56 and $345 \mathrm{mg} / \mathrm{L}$ with mean concentration of $210 \mathrm{mg} / \mathrm{L}$ (Table 3 and Fig. 16).

High level of potassium consumption through drinking water is not reported to cause adverse health effects in healthy persons. Rare intoxication of potassium is reported, due to the release of potassium very rapidly through healthy kidneys and vomiting occurs by ingestion of large level of potassium. High doses of salt substitutes have been described potassium toxicity for instance, heart failure, shortness of breath, hyperkalaemia, diarrhoea, vomiting, and nausea as well as chest tightness [47]. Potassium content of $11 \mathrm{mg} / \mathrm{L}$ was observed the maximum concentration in the water of the studied area; however, the lowest $\mathrm{K}$ content of $1.0 \mathrm{mg} / \mathrm{L}$ was measured from village Haji Gul Muhammad Jat. The average $\mathrm{K}^{+}$ level of $4.5 \mathrm{mg} / \mathrm{L}$ was determined from groundwater samples of 16 villages under study (Table 4 and Fig. 17).

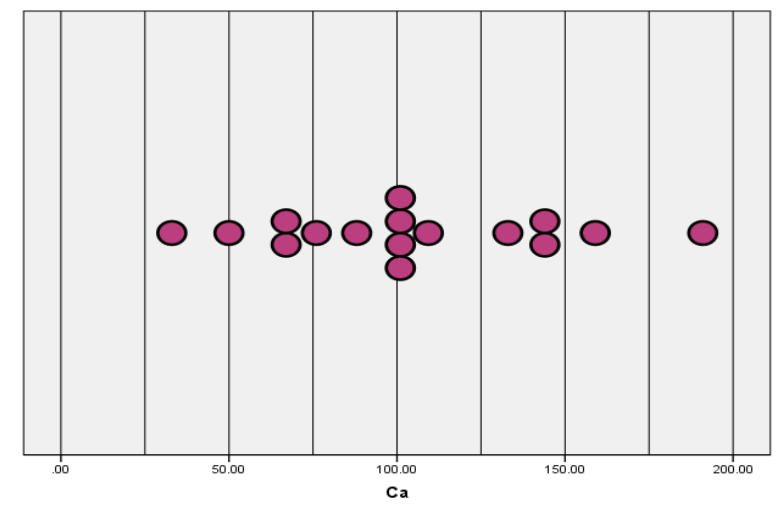

Figure 14. $\mathrm{Ca}^{2+}$

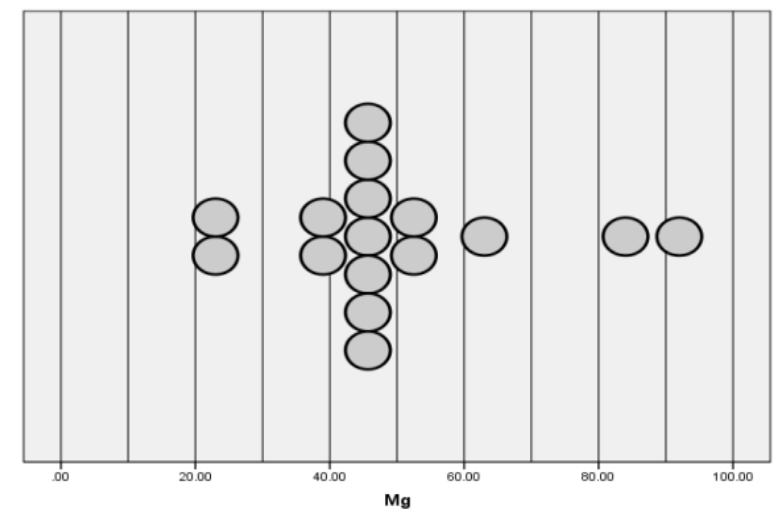

Figure 15. $\mathrm{Mg}^{2+}$ 


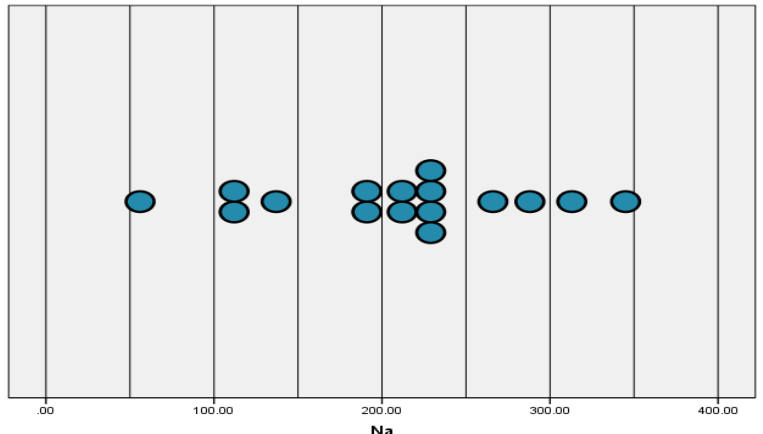

Figure 16. $\mathrm{Na}^{+}$

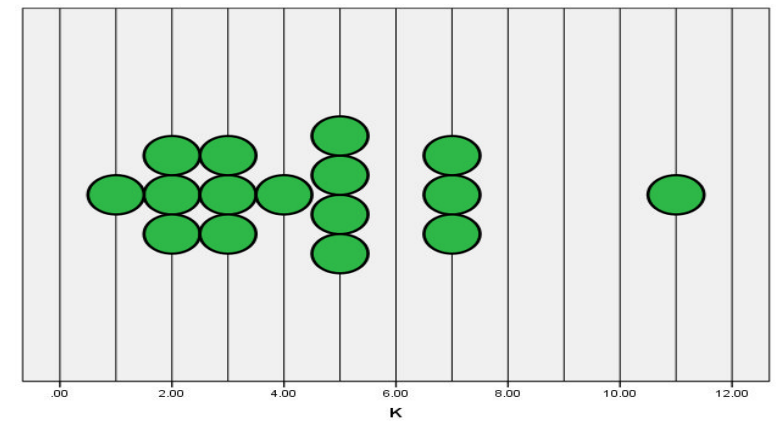

Figure 17. $\mathrm{K}^{+}$

Figures 14-17. Shows scatter plots of macro elements (metals) of area under study

Table 4. Cations content present in drinking water of area under study.

\begin{tabular}{|c|c|c|c|c|}
\hline Villages & $\mathrm{Ca}^{2+}(\mathrm{mg} / \mathrm{L}) \pm \mathrm{SD}$ & $\mathrm{Mg}^{2+}(\mathrm{mg} / \mathrm{L}) \pm \mathrm{SD}$ & $\mathrm{Na}^{+}(\mathrm{mg} / \mathrm{L}) \pm \mathrm{SD}$ & $\mathrm{K}^{+}(\mathrm{mg} / \mathrm{L}) \pm \mathrm{SD}$ \\
\hline R.M & $33 \pm 1.13$ & $24 \pm 1.80$ & $56 \pm 1.79$ & $2 \pm 0.07$ \\
\hline A.M.U & $101 \pm 1.69$ & $44 \pm 2.05$ & $218 \pm 2.44$ & $2 \pm 0.08$ \\
\hline E.B & $66 \pm 1.13$ & $45 \pm 1.81$ & $223 \pm 1.85$ & $5 \pm 0.09$ \\
\hline M.E.K & $76 \pm 1.14$ & $47 \pm 1.70$ & $137 \pm 1.84$ & $3 \pm 0.10$ \\
\hline A.M & $98 \pm 1.13$ & $51 \pm 1.69$ & $119 \pm 1.69$ & $3 \pm 0.13$ \\
\hline A.K & $68 \pm 1.17$ & $44 \pm 1.84$ & $198 \pm 2.24$ & $3 \pm 0.07$ \\
\hline H.G.M.J & $50 \pm 1.19$ & $22 \pm 1.69$ & $105 \pm 1.68$ & $1 \pm 0.12$ \\
\hline H.Y.M & $88 \pm 1.36$ & $41 \pm 2.24$ & $184 \pm 1.69$ & $5 \pm 0.20$ \\
\hline М.Н.P.В & $108 \pm 1.26$ & $63 \pm 1.75$ & $345 \pm 1.68$ & $7 \pm 0.05$ \\
\hline S.W & $159 \pm 1.30$ & $54 \pm 1.87$ & $234 \pm 1.72$ & $7 \pm 0.08$ \\
\hline H.Q.B.B & $101 \pm 1.44$ & $37 \pm 1.81$ & $288 \pm 1.73$ & $5 \pm 0.11$ \\
\hline N.K & $133 \pm 1.60$ & $44 \pm 1.76$ & $313 \pm 1.73$ & $4 \pm 0.18$ \\
\hline M.K.B & $144 \pm 1.17$ & $45 \pm 1.86$ & $266 \pm 2.15$ & $2 \pm 0.40$ \\
\hline A.H.M.B & $191 \pm 1.29$ & $92 \pm 1.75$ & $228 \pm 1.99$ & $11 \pm 0.20$ \\
\hline P.U.S.J & $144 \pm 1.18$ & $84 \pm 1.83$ & $235 \pm 1.75$ & $7 \pm 0.27$ \\
\hline B.T & $104 \pm 1.28$ & $47 \pm 1.70$ & $206 \pm 1.86$ & $5 \pm 0.10$ \\
\hline
\end{tabular}

\section{Statistical analyses}

The correlation coefficient among average physiochemical parameters of groundwater are given in Table 6 and 7 . Correlation coefficients showed that various physiochemical parameter pairs have significant positive correlation such as ECTH $\quad\left(r=0.847^{* *}\right), \quad$ TDS-TH $\left(r=0.847^{* *}\right)$, SulfTH $\quad\left(\mathrm{r}=0.783^{* *}\right), \quad$ Bicarb. $-\mathrm{TH} \quad\left(\mathrm{r}=0.732^{* *}\right)$, TDS-EC $\quad\left(\mathrm{r}=1.000^{* *}\right), \quad$ Alk-EC $\quad(\mathrm{r}=0.553)$, Alk-TDS $\quad\left(\mathrm{r}=0.553^{*}\right)$, Sulf -EC $\quad\left(\mathrm{r}=0.896^{* *}\right)$,
Sulf $-\mathrm{TDS}\left(\mathrm{r}=0.896^{* *}\right)$, Sulf - Alk $\left(\mathrm{r}=0.544^{*}\right)$, Bicarb -EC $\left(\mathrm{r}=0.854^{* *}\right)$, Bicarb -TDS $\left(\mathrm{r}=0.854^{* *}\right), \quad$ Bicarb-Sulf $\quad\left(\mathrm{r}=0.790^{* *}\right), \quad \mathrm{N}-\mathrm{N}-$ Bacarb $\left(\mathrm{r}=0.633^{* *}\right), \mathrm{Mg}-\mathrm{Ca} \quad\left(\mathrm{r}=0.781^{* *}\right), \mathrm{Na}-$ $\mathrm{Ca} \quad\left(\mathrm{r}=0.597^{*}\right), \mathrm{K}-\mathrm{Ca}\left(\mathrm{r}=0.707^{* *}\right)$ and $\mathrm{K}-\mathrm{Mg}$ $\left(\mathrm{r}=0.838^{* *}\right)$. Similarly, some pairs also showed a significant negative correlation such as EC-pH $\left(\mathrm{r}=-0.567^{*}\right)$ and TDS-pH ( $\mathrm{r}=-$ $\left.0.567^{*}\right)$. Descriptive statistics of various physicoch-emical parameters summarized in the Table 5 were also calculated. 
Pak. J. Anal. Environ. Chem. Vol. 21, No. 1 (2020)

Table 5. Descriptive Statistics of physical and chemical parameters in potable water of area under study.

\begin{tabular}{lcccc}
\hline & Minimum & Maximum & Mean & Std. Deviation \\
\hline $\mathrm{Ph}$ & 7.1 & 7.9 & 7.46 & 0.20 \\
$\mathrm{TH}$ & 66 & 694 & 281 & 174.37 \\
$\mathrm{EC}$ & 913 & 3580 & 1900 & 711.95 \\
$\mathrm{TDS}$ & 2399 & 1273 & 476.96 \\
$\mathrm{Cl}$ & 612 & 604 & 396 & 126.11 \\
$\mathrm{Alk}$ & 174 & 588 & 435 & 81.30 \\
Sulf & 330 & 292 & 109 & 61.05 \\
$\mathrm{Bicarb}$ & 49 & 460 & 264 & 99.53 \\
$\mathrm{NN}$ & 120 & 9.0 & 4.38 & 2.47 \\
$\mathrm{OPP}$ & 1.0 & 0.03 & 0.01 & 0.01 \\
$\mathrm{~F}$ & 0.01 & 0.36 & 0.26 & 0.05 \\
$\mathrm{Turb}$ & 2.3 & 1.47 & 0.52 \\
$\mathrm{Ca}$ & 0.17 & 191 & 104 & 41.10 \\
$\mathrm{Mg}$ & 0.25 & 92 & 49 & 18.21 \\
$\mathrm{Na}$ & 33 & 345 & 210 & 77.03 \\
$\mathrm{~K}$ & 22 & 11 & 4.5 & 2.58 \\
\hline
\end{tabular}

Table 6. Correlation coefficient among various physicochemical parameters of area under study.

\begin{tabular}{|c|c|c|c|c|c|c|c|c|c|c|c|c|}
\hline & $\mathrm{pH}$ & TH & EC & TDS & $\mathrm{Cl}^{-}$ & Alk & Sulf & Bicarb & NN & OPP & $\mathrm{F}^{-}$ & TURB \\
\hline $\mathrm{pH}$ & 1 & & & & & & & & & & & \\
\hline TH & -0.48 & 1 & & & & & & & & & & \\
\hline EC & $-.567^{*}$ & $.847^{* *}$ & 1 & & & & & & & & & \\
\hline TDS & $-.567^{*}$ & $.847^{* *}$ & $1.000^{* *}$ & 1 & & & & & & & & \\
\hline $\mathrm{Cl}^{-}$ & -0.473 & 0.33 & 0.494 & 0.494 & 1 & & & & & & & \\
\hline Alk & -0.469 & 0.353 & $.553^{*}$ & $.553^{*}$ & 0.185 & 1 & & & & & & \\
\hline Sulf & -0.37 & $.783^{* *}$ & $.896^{* *}$ & $.896^{* *}$ & 0.144 & $.544^{*}$ & 1 & & & & & \\
\hline Bicarb & $-.616^{*}$ & $.732^{* *}$ & $.854^{* *}$ & $.854^{* *}$ & 0.196 & 0.47 & $.790^{* * *}$ & 1 & & & & \\
\hline NN & -0.281 & 0.303 & 0.458 & 0.458 & 0.151 & 0.088 & 0.435 & $.633^{* *}$ & 1 & & & \\
\hline OPP & -0.064 & 0.282 & 0.334 & 0.334 & 0.393 & 0.001 & 0.261 & 0.1 & -0.285 & 1 & & \\
\hline $\mathrm{F}^{-}$ & 0.197 & 0.057 & 0.117 & 0.117 & -0.147 & 0.182 & 0.16 & 0.188 & 0.088 & -0.212 & 1 & \\
\hline Turb & -0.436 & 0.176 & 0.26 & 0.26 & 0.188 & -0.072 & 0.235 & 0.359 & 0.233 & 0.072 & -0.449 & 1 \\
\hline
\end{tabular}

. Correlation is significant at the 0.05 level (2-tailed)

**. Correlation is significant at the 0.01 level (2-tailed).

Table 7. Correlation coefficient among macro elements (metals) in water of area under study.

\begin{tabular}{lcccc}
\hline & Ca & Mg & Na & K \\
\hline $\mathrm{Ca}$ & 1 & & & \\
$\mathrm{Mg}$ & $0.781^{* *}$ & 1 & & \\
$\mathrm{Na}$ & $0.597^{*}$ & 0.419 & 1 & \\
$\mathrm{~K}$ & $0.707^{* *}$ & $0.838^{* *}$ & 0.473 & 1
\end{tabular}

**. Correlation is significant at the 0.01 level (2-tailed)

*. Correlation is significant at the 0.05 level (2-tailed)

\section{Conclusion}

From the present study it can be concluded that drinking water of villages, Rana Mori Stop, M. Essa Khaskheli, Abdullah Khatri, Haji Gul Muhammad Jat showed the most of the physical and chemical parameters like, $\mathrm{pH}, \mathrm{TH}$, EC, TDS, $\mathrm{Cl}^{-}$, alkalinity, $\mathrm{SO}_{4}{ }^{2-}, \mathrm{HCO}_{3}{ }^{-}, \mathrm{NO}_{3}{ }^{-} \mathrm{N}, o-$ $\mathrm{PO}_{4}^{3-}{ }_{4} \mathrm{P}, \mathrm{F}^{-}$, and Turbidity within permissible WHO limits. It is therefore suggested that water of 
these villages can be used for drinking purposes. While the drinking water in the rest of the villages was contaminated with $\mathrm{EC}$, TDS, $\mathrm{Cl}^{-}$, alkalinity, turbidity and sodium because these parameters were found above the permissible level of WHO guidelines. Higher $\mathrm{Na}^{+}$content was found in villages; Sajan Wari, Haji Qadir Bux Baloch, Nathoo Khan, Manjhi Khan Baloch, Ali Hassan Mirgh Baloch, Pir Usman Shah Jhaloo and Baghan Town. While $\mathrm{Ca}^{2+}, \mathrm{Mg}^{2+}$ and $\mathrm{K}^{+}$were found within allowable limits in water of all of the villages under study.

\section{References}

1. E. Jéquier and F. Constant. Eur. J. clin. Nutr., 64 (2010) 2. doi: 10.1080/07315724.2007.10719662.

2. D. Burns. Hydrol. Process An. Int. J., 19 (2005) 6. doi:10.1016/j.jhydrol.2005.01.022.

3. S. Chakrabarty and H. P. Sarma, Environ. Monit. Assess., 179 (2011) 479. doi:10.1007/s10661-010-1750-7.

4. S. A. Majidano, M. Y. Khuhawar and A. H. Channar, J. Chem. Soc. Pak., 32 (2010) 6. ISSN(0253-5106).

5. S. Zeb, A.H. Malik, A. Waseem and Q. Mahmood, Int. J. Phys. Sci., 6 (2011) 7789. doi: 10.5897/IJPS11.1385.

6. A. J. Kandhro, A. M. Rind, A. A. Mastoi, K. F. Almani, S. Meghwar, M. A. Laghari and M. S. Rajpout, Am. J. Environ. Prot., 41, (2015) 62.

doi: 10.11648/j.ajep.20150401.19.

7. A. Shahab, S. Qi, M. Zaheer, A. Rashid, M.A. Talib, and U. Ashraf, Int. J. Agri. Biol. Eng., 11 (2018) 115.

doi: 10.25165/j.ijabe.20181102.2747

8. S. H. Chandio, S. M. Ahmed, W. Saleem, S. Naeem, S. U. A. Bhutto and M. A. Sanjrani, Eurasian J. Sci. Eng., 4 (2019) 1. doi: 10.23918/eajse.v4i4p1

9. S. Shakoor, I. Ahmed, S. Mukhtiar, I. Ahmed, F. Hirani, S. Sultana and R. Hasan, BMC Res. Notes, 11 (2018) 350. https://doi.org/10.1186/s13104-018-3461-z

10. M. J. Khan, B. A. Shah and B. Nasir, Mod. Ear. Sys. Environ., 6 (2020) 1. doi:org/10.1007/s40808-019-00676-X
11. F. Deeba, N. Abbas, M. Butt, M. Irfan F. Deeba, N. Abbas, M. T. Butt and M. Irfan, Chem. Int., 5 (2019) 241. doi.org/10.5281/zenodo.2573563

12. S. Muhammad, M. T. Shah and S. Khan. Microchem. J., 98 (2011) 2. doi:10.1016/j.microc.2011.03.003.

13. M. T. Shah, J. Ara, S. Muhammad, S. Khan and S. Tariq, J. Geochem. Explor., 118 (2012) 60 .

doi:10.1016/j.gexplo.2012.04.008.

14. S. Khan, M. Shahnaz, N. Jehan, S. Rehman, M.T. Shah and I. Din, J. Cleaner Prod., 60 (2013) 93.

doi: org/10.1016/j.jclepro.2012.02.016

15. K. D. Brahman, T. G. Kazi H. I. Afridi, Sci. Total Environ., 544 (2016) 653.

doi:10.1016/j. scitotenv.2015.11.152.

16. D. Chakraborti, M. M. Rahman, S. Ahamed, R. N. Dutta, S. Pati, S. C. Mukherjee. Chemosphere, 152 (2016) 520. doi:10.1016/j.chemosphere.2016.02.119.

17. M. Kumar, M. M. Rahman, A. Ramanathan, and R. Naidu, Sci. Total Environ., 539 (2016) 125. doi:10.1016/j.scitotenv.2015.08.039.

18. F. B. Asghari, J. Jaafari, M. Yousefi, A. A. Mohammadi and R. Dehghanzadeh, Hum. Ecol. Risk. Assess. Int. J., 24 (2018) 1138. doi:10.1080/10807039.2017.1407632.

19. F. Savino, S. Maccario, C. Guidi, E. Castagno, D. Farinasso, F. Cresi, L. Silvestro and G. C. Mussa, Ann. Nutr. Metab., 50 (2006) 368. doi.org/10.1159/000094301.

20. A. A. Chetty and S. Prasad, Food Chem., 197 (2016) 503. doi:10.1016/j.foodchem.2015.10.079.

21. V. K. Moghaddam, M. Yousefi, A. Khosravi, M. Yaseri, A. H. Mahvi, M. Hadei, A. A. Mohammadi, Z. Robati and A. Mokammel, Biol. Trace Elem. Res., 185, (2018) 262. doi:org/10.1007/s12011-018-1250-0.

22. M. Yousefi, M. H. Dehghani, S. M. Nasab, V. Taghavimanesh, S. Nazmara and A. A Mohammadi, Data Brief, 17 (2018) 424. doi:10.1016/j.dib.2018.01.032.

23. M. Mirzabeygi, N. Yousefi, A. Abbasnia, H. Youzi, M. Alikhani and A. H. Mahvi, J. 
Water Supply Res. Technol. Aqua., 67 (2017).

doi:10.2166/aqua.2017.128.

24. R. Jacobsen, J. K. Lorenzen, S. Toubro, I. Krog-Mikkelsen and A. Astrup, Int. J. Obes., 29 (2005) 292. doi:10.1038/sj. ijo.0802785.

25. H. Soleimani, A. Abbasnia, M. Yousefi, A. A. Mohammadi and F. C. Khorasgani, Data Brief, 17 (2018) 148. doi:10.1016/j.dib.2017.12.061.

26. S. Baloch, F. K. Chang, M. Sana and M. I. Kumbhar, Int. J. Environ. Sci. Nat. Res., 20 (2019) 5. doi: 10.19080/IJESNR.2019.20.556048

27. A. Alamgir, M. A. Khan, I. Manino, S. S. Shaukat and S. Shahab, Desal. Water Treat., 57 (2016) 40. doi: 10.1080/19443994.2015.1094418

28. "Shah Jahan Mosque, Thatta". UNESCO. Retrieved 17 July 2017.

29. Pakistan flood victims flee Thatta. The Guardian. Retrieved 27 December 2010.

30. S. Khan, R. Rauf, S. Muhammad, M. Qasim and I. Din, Hum. Ecol. Risk. Assess., Int. J. 22 (2015) 581. doi: 10.1080/10807039.2015.1083845.

31. A. D. Eaton, L. S. Clesceri, E. W. Rice, A. E. Greenberg and M. A. H. A. Franson, Centennial Edition., APHA, AWWA, WEF, Washington, DC. (2005).

32. P. Quevauviller and K. C. Thompson, John Wiley Sons., 26 (2009) 53.

ISBN: 978-0-470-05811-4

33. C. C. Chang, C. C. Chen, D. C. Wu and C. Y. Yang, J. Toxicol. Environ. Health, Part A, 73 (2010) 1337. doi:org/10.1080/15287394.2010.490178

34. S. Iram, S. Kanwal, I. Ahmad, T. Tabassam, V. Suthar and M. Mahmood-ul-Hassan, Environ. Monit. Assess., 185 (2013) 2503. doi: 10.1016/j.ocecoaman.2013.11.005

35. M. K. R. Mudiam, S. P. Pathak, K. Gopal, and R. C. Murthy, Environ. Monit. Assess., 184 (2012) 461. doi: 10.1007/s10661-011-1980-3

36. M. Jaishankar, T. Tseten, N. Anbalagan, B. B. Mathew and K. N. Beeregowda, Interdis. Toxicol., 7 (2014) 60. doi:org/10.2478/intox-2014-0009.
37. H. K. Okoro, A. Adeyinka, O. E. Jondiko and B. J. Ximba, Sci. Res. Essays, 7 (2012) 2063.

doi: 10.5897/SRE11. 1889

38. M. Jeyaraj, K. Ramakrishnan, A. J. Anandhi, S. Arunachalam and P. N. Magudeswaran, Orient J. Chem., 32 (2016) 4. 2087. doi:org/10.13005/ojc/320436.

39. P. J. Sajil Kumar, E. J. James, Appl. Water Sci., 3 (2013) 219.

https://doi:org/10.1007/s13201-012-0074-x.

40. R. P. Gale, R. E. Champlin, S. A. Feig and J. H. Fitchen,. Ann. Inter. Medi., 95 (1981) 477.

https://doi:org/10.7326/0003-4819-954-477.

41. M. E. Gates Jr, E. C. Julian and R. C. Kroner, J. Am. Water Works Ass., 58 (1966) 1363. https://doi.org/10.1002/j.15518833.1966.tb01703.x.

42. G. Meenakshi, R. Karik and A. Malik, J. Hazard. Mater., 106 (2004) 85.

https://doi:org/10.1016/j.jhazmat.2003.09.00 $\underline{7}$.

43. M. F. Lanjwani, M. Y. Khuhawar, T. M. J. Khuhawar, A. H. Lanjwani, M. S Jagirani, A. H. Kori, I. K. Rind, A. H. Khuhawar and M. D. Jagirani, Geo. Eco. Land, 4 (2020) 23.

doi: 10.1080/24749508.2019.1571670.

44. D. S. Lloyd, J. P. Koenings and J. D. Laperriere. North Am. J. Fish Manag., 7 (1987) 1. https://doi:org/10.1577/15488659(1987)7<18:EOTIFW>2.0.CO;2

45. I. Rosborg, F. Kozisek and V. Soni, Springer Cham., (2019) 101. https://doi:org/10.1007/978-3-030-18034$\underline{8 \_}$

46. A. Pomeranz, T. Dolfin, Z. E. Korzets, A. Eliakim and B. Wolach, J. Hyper, 20 (2002) 203. doi: 00004872-200202000-00009.

47. R. H. Grimm, P. M. Kofron, J. D. Neaton, K. H. Svendsen, P. J. Elmer, L. Holland, L. Witte, D. Clearman and R. J. Prineas, J. Hyper. Suppl., 6 (1988) S591. doi: 10.1097/00004872-198812040-00185. 